\title{
Fish diet composition in permanent and semi-permanent pools in tropical wetlands of the Yucatan Peninsula
}

\author{
Demián Hinojosa-Garro ${ }^{1}$, Joselito Arceo-Gómez ${ }^{1}$, Luis Zambrano ${ }^{2}$ and \\ Luis H. Escalera-Vázquez ${ }^{2}$
}

We compared fish diet composition between permanent (P) and semi-permanent (SP) pools in Petenes Biosphere Reserve (PBR), Campeche. A total of 445 gut contents were examined to determine stomach relative fullness (RF), fish diet as index of niche breadth (INB) and diet overlap. In SP pools, species showed a RF of 1.66 (57.20 \% empty stomachs) whereas in P pools, the RF was 2.91 (31.16\%). We classified fish diet into six trophic groups: detritivorous, herbivorousdetritivorous, insectivorous, piscivorous, omnivorous and malacophagous. Species in P pools were found to be specialist. Conversely, species present in both habitats shifted to generalist patterns. There was a $54.0 \%$ dissimilarity in fish diet composition between pools. From all items identified, detritus $(21.33 \%$ of the total dissimilarity), aquatic and terrestrial invertebrates (12.31\%), fish remains (10.29\%), plant remains $(7.37 \%)$, and crustaceans $(2.74 \%)$ distinguished diets between pools. Significant diet overlaps $(>0.6)$ and low INB values $(<0.3)$ were observed in P pools, whereas in SP pools, intermediate-low diet overlaps $(<0.4)$ and higher INB values $(>0.5)$ were observed. In SP pools seasonality had a strong effect on fish diet, increasing the frequency of food items such as terrestrial insects, amphipods and arachnids, during the rainy season while P pools showed lower variation. Thus, fish trophic habits appear to be regulated by pools hydrology.

Se analizaron y compararon los contenidos estomacales de la ictiofauna en cuerpos de agua permanentes (P) y semipermanente (SP) de la reserva de la Biosfera Los Petenes, Campeche. Se analizaron un total de 445 estómagos en los cuales se determino la diversidad de dieta (como Índice de amplitud de nicho = INB), plenitud relativa de estómagos (PRE) y traslape de dietas. En las pozas SP $57.20 \%$ de los estómagos se encontraron vacíos y los estómagos con alimento presentaron un PRE de 1.66. En las pozas P solo el $31.16 \%$ de los estómagos se encontraron vacíos y un PRE de 2.91. Los peces se clasificaron en seis grupos tróficos: detritívoros, herbívoros-detritívoros, insectívoros, piscívoros, omnívoros y malacófagos. Los individuos en la pozas P tendieron a presentar dietas especializadas mientras que en las pozas SP patrones generalistas. Se observo una disimilitud de dietas entre pozas del 54.0 \% asociada a los items: detritus (21.33\%), invertebrados acuáticos y terrestres $(12.31 \%)$, fragmentos de peces $(10.29 \%)$, fragmentos de vegetación $(7.37 \%)$ y crustáceos $(2.74 \%)$. Los mayores traslapes de dietas $(>0.6)$ y menores INB $(<0.3)$ se observaron en especies presentes en las pozas $\mathrm{P}$ mientras que en las pozas SP se observaron valores de traslape intermedios-bajos $(<0.4)$ e INB mayores $(>0.5)$ en especies que utilizaron mayores fuentes de alimento. En las pozas SP la estacionalidad tuvo una marcada influencia en la proporción de los ítems: insectos acuáticos, anfípodos y arácnidos, los cuales presentaron mayores frecuencias, sobre todo en la época de lluvias, mientras que las pozas P no presentaron cambios significativos. Los resultados sugieren que los peces en pozas de la RBP modifican su dieta en función de la hidrología de los cuerpos de agua, con un patrón trófico particular a escala regional comparado con otros cuerpos de agua estacionales en Centro y América del Sur.

Key words: Campeche, Feeding ecology, Freshwater fish, Mexico, Petenes Biosphere Reserve.

\footnotetext{
${ }^{1}$ Laboratorio en Manejo de Vida Silvestre y Colecciones Científicas, Área de Ecología Acuática, CEDESU, Universidad Autónoma de Campeche, San Francisco de Campeche, Campeche, México; dhinojos@uacam.mx (DHG), joselitochiva@hotmail.com (JAG)

${ }^{2}$ Laboratorio de Restauración Ecológica, Instituto de Biología, UNAM. Ciudad Universitaria, México D.F. zambrano@ibiologia.unam.mx (LZ), lhescalera@ibiologia.unam.mx (LHEV)
} 


\section{Introduction}

In shallow coastal freshwater wetlands of the Yucatan peninsula, small water bodies such as permanent $(\mathrm{P})$ and semi-permanent (SP) pools are common elements of the landscape (Contreras-Espinosa \& Warner, 2004; Zambrano et al., 2006). On a regional scale, these shallow aquatic systems promote ecotones, which support a unique freshwater fish diversity in southern Mexico and Central America (Miller, 2009; Cochran-Biederman \& Winemiller, 2010). Tropical wetlands are characterized by drying and flooding regimes in which the water level decrease considerably and remains low for more than six months of the year (Hinojosa-Garro et al., 2009; Escalera-Vázquez \& Zambrano, 2010). This represents harsh conditions in dry seasons for the fish community, particularly in those SP habitats that exhibit significant changes in water quality, food sources and sites for reproduction (Escalera-Vázquez $\&$ Zambrano, 2010). Hence, fish assemblages and diets are expected to differ between pools based on habitat heterogeneity, hydrological conditions and connectivity between systems (Taylor, 1997). Seasonality has been suggested to cause significant changes in food sources and to modify fish diets (Hahn et al., 2004; Yamamoto, 2004; Silva et al., 2012). As a result, fish respond by either sharing food sources (niche overlap) or shifting their feeding habits by using more and different food sources (Hahn et al., 2004; Mérona \& Mérona 2004; Pouilly et al., 2006; Silva et al., 2012). However, it is not clear whether this occurs in fish species of P and SP pools in the Yucatan peninsula. Studies have described fish diets in $\mathrm{P}$ water bodies of Quintana Roo and Yucatan (Navarro-Mendoza, 1988; Martínez-Palacios \& Ross, 1994; Valtierra-Vega \& Schmitter-Soto, 2000), but none in karstic water bodies of Campeche. Petenes Biosphere Reserve (PBR), Campeche, is located in southern Mexico and comprises shallow freshwater coastal $\mathrm{P}$ and SP pools in wetlands. The region experiences high seasonal rainfall, but precipitation varies within the reserve, promoting $\mathrm{P}$ and SP pools. Previous studies by Torres-Castro et al. (2008) and Hinojosa-Garro et al. (2009) in these pools have described clustering of fish species based on pool hydrology. A reduction in prey abundance has also been observed in SP pools during the dry season, particularly for aquatic insect and gastropod diversity (Hinojosa-Garro et al., 2009). Conversely, most $\mathrm{P}$ pools receive spring water from phreatic karstic systems that support a higher richness of fish and aquatic insect communities than in SP pools (Hinojosa-Garro et al., 2009). Considering these features, we can address some basic questions: i) Do fish feeding habits and diets differ in $\mathrm{P}$ pools compared to SP pools in the PBR? ii) Which prey are the most frequent food sources for fish in $\mathrm{P}$ and SP pools in the PBR? iii) Is there any diet overlap between fish species in the pools of PBR? We addressed these questions in a year-long study in P and SP pools in the PBR during 2010. The present study provides information about fish ecology in tropical wetlands; results are discussed in relation to the management and conservation knowledge of differences in fish diets in wetlands of the PBR, Campeche, in the Yucatan peninsula.

\section{Material and Methods}

\section{Study site}

Sampling took place during 2010 in the PBR (20 $51^{\prime} 30^{\prime}$ 'N, $\left.19^{\circ} 49^{\prime} 00^{\prime \prime} \mathrm{W}\right)$. The PBR is comprised of 100,939 ha terrestrial ecosystem and 181,919 ha marine-coastal ecosystem (total area of 282,857 ha; Fig. 1). The PBR is a freshwater wetland located along the northeastern part of the State of Campeche (CONANP, 2006). These wetlands have a strong seasonal rainfall pattern, receiving most precipitation from May to October, with the driest period in April (García, 1973; CONANP, 2006). There is a precipitation gradient across the reserve and the northern area is drier $(725.5 \mathrm{~mm} /$ year $)$ than the southern area (1,049.7 mm/year) (Garcia, 1973). During the study, most of the wetland reached its maximum water level at the end of September. This freshwater wetland consists of a series of sandy-muddy bottomed eutrophic $\mathrm{P}$ pools $<20 \mathrm{~m}$ in diameter and $<2$ m deep, associated with riparian species such as saw grass (Cladium jamaicense), cattail (Typha dominguensis) and water lily (Nymphaea ampla) (Hinojosa-Garro et al., 2009). These systems constantly receive water from phreatic karstic systems, which interconnect pools through a wide variety of small streams and channels. In contrast, SP pools $(<10 \mathrm{~m}$ in diameter and $<0.5 \mathrm{~m}$ deep) are muddy-bottomed mesotrophic pools, found in association with mats of musk grass (Chara sp.) and spike rush (Eleocharis cellulosa) (Hinojosa-Garro et al., 2009). These systems reached their lowest water level (2 $\mathrm{cm}$ ) during April/May and some dried out for up to a month. In a previous study, Hinojosa-Garro et al. (2009) reported 17 continental freshwater fish species from the PBR; the Cichlidae, Poeciliidae, Characidae and Rivulidae were the most representative fish families in this area.

We classified the reserve into two main areas (north and south) and selected a total of six P and five SP pools $(n=11)$ throughout the reserve, considering pools that did not dry out completely (Fig. 1). Pools were selected along the terrestrial ecotone on the inland part of the reserve to avoid salt-water intrusion. Salinity concentrations above $5 \%$ were present 2 $\mathrm{km}$ from the seashore. Most pools were placed from 5 to $8 \mathrm{~km}$ inland, reaching salinities of 1.5 to $2.5 \%$.

\section{Fish sampling}

Fish were sampled every two months from April 2010 to February 2011 during daylight. A cast net ( $2 \mathrm{~m}$ in diameter, 1.5 $\mathrm{cm}$ mesh size) was deployed five times in each pool near the shoreline. Care was taken to avoid interference by macrophytes, stones or wood remains present in each pool. An electro-fisher (Smith and Root LR-24, backpack electrofishers) was used in areas with macrophytes, stones and/or plant remains in which cast net sampling efficiency was limited. In all pools, three bouts along 10 seconds each shot were performed at 400 volts, 


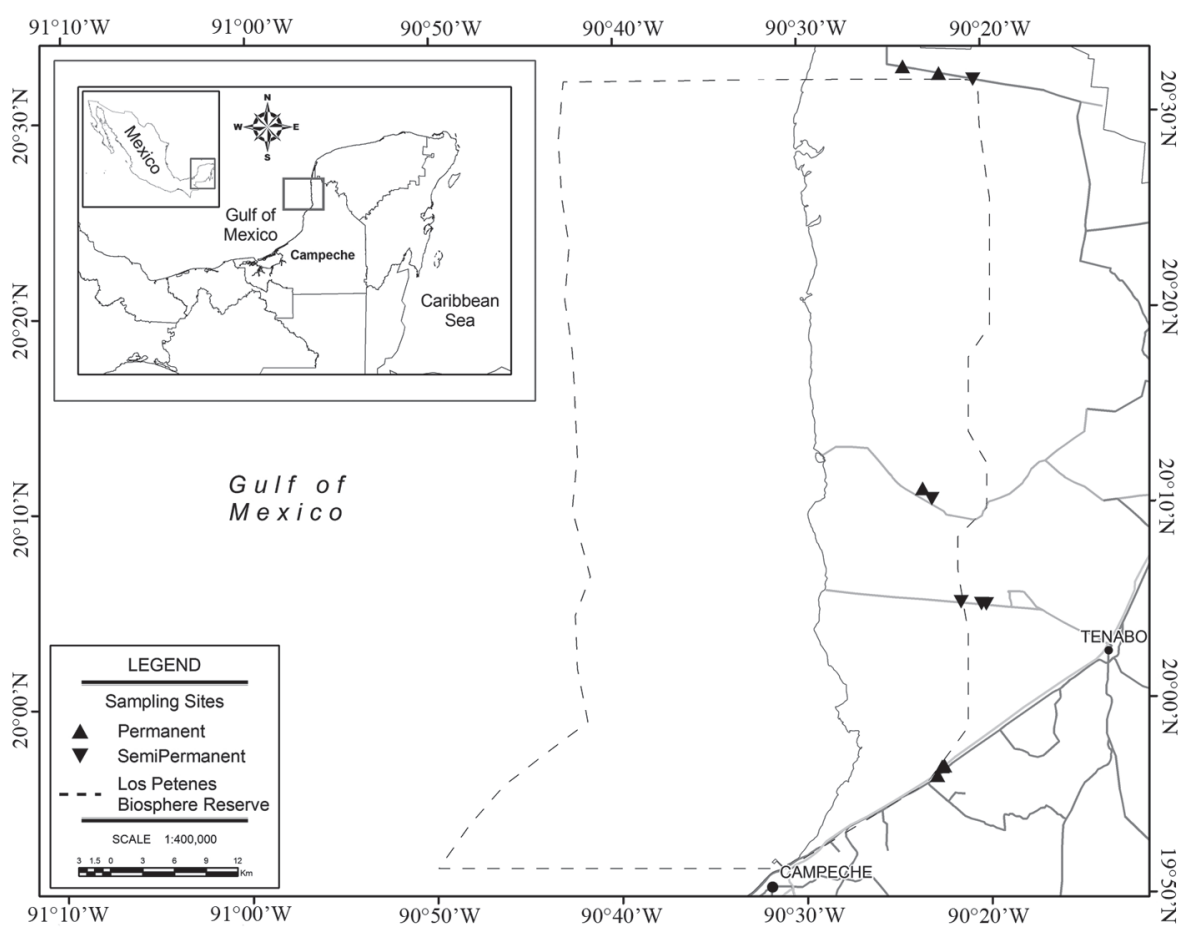

Fig. 1. Geographic location of studied pools, permanent and semi-permanent in PBR, Campeche, Mexico during 2010.

dual cycle $30 \mathrm{~Hz}$ cycle frequency and $500 \mathrm{~Hz}$ pulses. Following sampling, fish were anesthetized with benzocaine $(250 \mathrm{mg} / \mathrm{L})$ (Silva et al., 2012). Fish were identified according to SchmitterSoto (1998) and Miller (2009). Fish samples catalog numbers: UAC-LVSCS-PP2010-\#1-445.

\section{Fish diet determination}

Collected fish were immediately preserved in 5\% formalin for $48 \mathrm{~h}$ in $20 \mathrm{~L}$ buckets to allow fixation of tissues. In the laboratory, fish were counted, weighed and the standard length (SL) was measured. Fish stomachs were then dissected and transferred to $90 \%$ ethanol for storage in $50 \mathrm{ml}$ flasks. Stomach contents were dissected onto a glass dish and observed under a microscope at $2 \mathrm{x}$ and $4 \mathrm{x}$ magnification (Nikon, SMZ645). Each item was sorted carefully and excess alcohol was removed with a dry paper towel. Items were then weighed using an analytical balance (Acculab, VICON-303) to obtain their proportion by wet weight $(\% \mathrm{~W}=$ gravimetric) in the $\operatorname{diet}$ (Hyslop, 1980). This method allowed the proportion of the items to be analyzed independently of the degree of stomach fullness and volume uniformity (Lima-Junior \& Goitein, 2001). The percentage of empty stomachs was determined for each species, whereas the relative stomach fullness was assessed as $1=$ empty, $2=<50 \%$ filled, $3=>50 \%$ filled and $4=$ bursting. Diet diversity (based on identified items) was estimated by an index of the niche breadth (INB; Levins, 1968) that was calculated by:

$$
B i=\frac{1}{(n-1)}\left(\frac{1}{\left(\sum_{j} p_{i j}^{2}\right)}-1\right)
$$

where $\mathrm{B}_{i}=$ the index for species $i, p i j=$ the proportion of diet of species $i$ that is made up of food item $j$ and $n=$ the number of prey categories. Values were set at the following levels: high $(>0.6)$, intermediate $(0.4-0.6)$ and low $(<0.4)$ (Levins, 1968). Low values indicate a specialized diet (S) while intermediate and high values indicate a generalist diet $(\mathrm{G})$ (Levins, 1968). Dietary overlap between species was calculated from Pianka's index (1974):

$$
O_{j k}=\frac{\sum_{i}^{n} p_{i j} p_{i k}}{\sqrt{\sum_{i}^{n} p_{i j}{ }^{2} \sum_{i}^{n} p_{i k}{ }^{2}}}
$$

where $O_{j k}=$ the diet overlap coefficient between species $j$ and $k, \mathrm{P}_{i j}$ and $\mathrm{P}_{i k}=$ the proportion of food item $i$ in the diet of species $j$ and $k$. The values of this index ranged as follows: high (>0.6), intermediate $(0.4-0.6)$ or low $(<0.4)$ (Grossman, 1986; Dias \& Fialho, 2011). This index assumes prey to be equally available to all predators (Reinthal, 1990). Values $>0.6$ were considered to represent a biologically significant overlap (Langton, 1982). Fish trophic classification was performed based on a modification of Schlosser (1982) and Karr et al. (1986). Omnivorous (O) species mainly consume plant and animal remains (>25\%); Herbivore-detritivores (HD) species diet was almost entirely conformed by detritus and algae (diatoms and macroalgae); insectivorous (I) species diet consist of animal and plant materials, including terrestrial aquatic invertebrates ( $>25 \%$ ); piscivorous $(\mathrm{P})$ species diet mainly consist of small fish and some times aquatic insects; malacophagous (M) species diet mainly consist of gastropod 
$(>25 \%)$ and some aquatic insects. Fish diet similarity analysis between pools was carried out using one-way analysis of similarities (ANOSIM) using the Primer 6 Statistical Package 6.1.6 (Clarke \& Gorley, 2006). SIMPER was conducted to evaluate items contribution to fish diet dissimilarity between pools and between seasons (dry and rainy). Student- $t$ test was used to compare variations in aquatic and terrestrial invertebrates frequencies between pools and seasons (Systat 11.0, Systat Software, 2010).

\section{Results}

Captured fish consisting of 13 species and four families, 12 species were recorded in $\mathrm{P}$ pools, compared with six species in SP pools. Garmanella pulchra was found in SP pools for the first time in PBR water bodies. The richest family was the Cichlidae, with seven species, followed by the Poeciliidae with four species, whereas the Characidae and Cyprinodontidae had a single species each. A total of 445 stomachs were examined; on average $57.20 \%$ of fish stomachs were empty in SP pools with a relative fullness of 1.66 , whereas in $P$ pools, these values were $31.16 \%$ and 2.91 , respectively (Table 1 ).

Eight main trophic resources comprised the fish diet: Detritus, plant remains, macroalgae (mainly Chara sp.), aquatic insects (Diptera, Heteroptera, Odonata, and Coleoptera), terrestrial invertebrates (Hymenoptera, Orthoptera, Myriapoda, and Arachnida), Crustaceans (Amphipoda), Gastropoda (mainly Hydrobiids such as Pyrgophorus sp.) and fish remains (Table 2). Detritus represented $58.6 \%$ on average of the fish diet in $\mathrm{P}$ pools, compared with $44.7 \%$ in SP pools. Aquatic and terrestrial invertebrates comprised on average $27 \%$ and $16.6 \%$, respectively, of the fish diet in SP pools, whereas fish and plant remains accounted for $12.7 \%$ and $8.9 \%$, respectively, of the diet in P pools (Table 2).

Fish exhibited six trophic habits: Detritivorous (D) were highly represented in both types of habitats, followed by herbivorous-detritivorous (HD), insectivorous (I), piscivorous $(\mathrm{P})$, omnivorous $(\mathrm{O})$, and malacophagous (M) (Table 3). Notably, there was a clear shift in habits in those species present in both habitats. Astyanax aeneus showed I/HD and I/O habits respectively in P pools and SP pools; Gambusia yucatana $\mathrm{O}$ and I habits; Rocio octofasciata $\mathrm{D}$ and $\mathrm{O}$ habits, including a higher proportion of terrestrial insects and arachnids in its diet in SP pools (Table 3; Fig 2).

Cichlasoma urophthalmus showed D/O habits in P pools, whereas Thorichthys meeki was the only species classified as $\mathrm{M} / \mathrm{D}$ which fed selectively on gastropod and detritus in $\mathrm{P}$ pools. Belonesox belizanus and Petenia splendida were strictly piscivorous species. When the INB was compared, cichlids, poeciliids, and cyprinodontids showed low values in both types of pools. Conversely, R. octofasciata and $A$. aeneus in SP pools showed the highest INB from all species analyzed (Table 2). Fish species showed specialist diets in $\mathrm{P}$ pools and a tendency to generalist diets in SP pools (Table 3). ANOSIM showed that the diets of $B$. belizanus, $P$. splendida, Paraneetroplus melanurus, A. aeneus, and G. yucatana were significantly different from all other species analyzed (ANOSIM Global $R=0.28, p<0.05$, in all cases). SIMPER described $54 \%$ dissimilarity in fish diet composition between pools. Detritus (21.33\% of the total dissimilarity), aquatic insects and terrestrial invertebrates $(12.31 \%)$, fish remains $(10.29 \%)$, plant remains $(7.37 \%)$ and crustaceans $(2.74 \%)$, were observed in different proportions between species, and thus showed differential diets to exist between pools. Invertebrate groups represented a large portion of the fish diet, showing significant differences in invertebrate use by fish between pools. Diptera, Amphipoda, Gastropoda, and Odonata had significant higher frequencies in fish of $\mathrm{P}$ pools compared to SP pools $(t=2.04,1.98$ and 1.78, 1.69, $p<0.05, n=13$, respectively) (Fig. 2). The most consumed invertebrates in $\mathrm{P}$ pools were Diptera (Poecilia velifera, $R$. octofasciata and $G$. pulchra), Gastropoda (T. meeki) and Odonata (Cichlasoma salvini and C. urophthalmus). Orthoptera remains were

Table 1. Individual fish collected $(\mathrm{N})$, the proportion with empty stomachs and the relative fullness $(1=$ empty, $2=<50 \%$ filled, $3=>50 \%$ filled and 4 bursting) of stomachs containing food items in pools of the PBR during 2010. $\mathrm{P}=$ permanent and SP $=$ semi-permanent pools. Mean values are showed in bold.

\begin{tabular}{cccccccc}
\hline \multirow{2}{*}{ Family } & \multirow{2}{*}{ Species } & \multicolumn{3}{c}{ Empty Stomachs (\%) } & \multicolumn{2}{c}{ Relative Fullness } \\
\cline { 3 - 7 } & & $\mathrm{P}$ & $\mathrm{SP}$ & $\mathrm{P}$ & $\mathrm{SP}$ & $\mathrm{P}$ & $\mathrm{SP}$ \\
\hline Cichlidae & Rocio octofasciata & 11 & 13 & 75 & 75 & 2 & 1 \\
Cichlidae & Cichlasoma salvini & 31 & - & 67 & - & 2 & - \\
Cichlidae & Cichlasoma urophthalmus & 16 & - & 0 & 0 & 4 & - \\
Cichlidae & Oreochromis niloticus & 16 & - & 0 & - & 4 & - \\
Cichlidae & Petenia splendida & 10 & - & 50 & - & 2 & - \\
Cichlidae & Thorichthys meeki & 31 & - & 45 & - & 2 & - \\
Cichlidae & Paraneetroplus melanurus & 25 & - & 25 & - & 3 & - \\
Poecilidae & Gambusia yucatana & 37 & 10 & 35 & 83 & 3 & 2 \\
Poecilidae & Poecilia mexicana & 15 & 12 & 0 & 33 & 4 & 2 \\
Poecilidae & Belonesox belizanus & 22 & - & 67 & - & 2 & - \\
Poecilidae & Poecilia velifera & 29 & 17 & 7 & 75 & 4 & 1 \\
Characidae & Astyanax aeneus & 110 & 30 & 3 & 20 & 3 & 3 \\
Cyprinodontidae & Garmanella pulchra & - & 10 & - & 0 & - & 1 \\
\hline & & & $\mathbf{3 1 . 1 6}$ & $\mathbf{5 7 . 2 0}$ & $\mathbf{2 . 9 1}$ & $\mathbf{1 . 6 6}$ \\
\hline
\end{tabular}


Table 2. The proportion (by wet weight) of food resources in the diet of 13 fish species and Index of niche breadth (INB) in Permanent (P) and semi-permanent (SP) pools of the PBR, during 2010. * Resources with $<10 \%$ wet weight in fish diet. Resources with greater contribution to diet comprisal are in bold.

\begin{tabular}{|c|c|c|c|c|c|c|c|c|c|c|c|c|c|c|c|c|c|c|c|c|c|c|}
\hline \multirow{3}{*}{ Species } & & & & & \multicolumn{16}{|c|}{ Items } & \multirow{2}{*}{\multicolumn{2}{|c|}{ INB }} \\
\hline & \multicolumn{2}{|c|}{ TL (cm) } & \multicolumn{2}{|c|}{$\mathrm{N}$} & \multicolumn{2}{|c|}{ Detritus } & \multicolumn{2}{|c|}{$\begin{array}{c}\text { Plant } \\
\text { Remains }\end{array}$} & \multicolumn{2}{|c|}{ Algae } & \multicolumn{2}{|c|}{$\begin{array}{l}\text { Aquatic } \\
\text { Insect }\end{array}$} & \multicolumn{2}{|c|}{ Crustacean } & \multicolumn{2}{|c|}{ Gastropod } & \multicolumn{2}{|c|}{$\begin{array}{c}\text { Terrestrial } \\
\text { invertebrate }\end{array}$} & \multicolumn{2}{|c|}{$\begin{array}{c}\text { Fish } \\
\text { Remains }\end{array}$} & & \\
\hline & $\mathrm{P}$ & SP & $\mathrm{P}$ & SP & $\mathrm{P}$ & SP & $\mathrm{P}$ & SP & $\mathrm{P}$ & SP & $\mathrm{P}$ & SP & $\mathrm{P}$ & SP & $\mathrm{P}$ & SP & $\mathrm{P}$ & SP & $\mathrm{P}$ & SP & $\mathrm{P}$ & SP \\
\hline $\begin{array}{l}\text { Astyanax } \\
\text { aeneus }\end{array}$ & $5.7-10.4$ & $3.4-7.4$ & 110 & 30 & 31.61 & 44.89 & 34.96 & $*$ & 30.28 & - & - & $*$ & - & $*$ & - & $*$ & * & $*$ & - & 45.87 & 0.31 & 0.55 \\
\hline $\begin{array}{l}\text { Cichlasoma } \\
\text { urophthalmus }\end{array}$ & 6-11.9 & $5.8-7$ & 16 & - & 55.09 & - & 27.52 & - & $*$ & - & $*$ & - & - & - & $*$ & - & - & - & 12.42 & - & 0.30 & - \\
\hline $\begin{array}{l}\text { Thorichthys } \\
\text { meeki }\end{array}$ & $4.5-12$ & - & 31 & - & 29.29 & - & $*$ & - & - & - & $*$ & - & * & - & 59.29 & - & * & - & $*$ & - & 0.20 & - \\
\hline $\begin{array}{l}\text { Gambusia } \\
\text { yucatana }\end{array}$ & $1.4-7.3$ & $1.3-3.9$ & 37 & 10 & 36.89 & 10.52 & $*$ & - & $*$ & - & 54.40 & 89.47 & $*$ & - & $*$ & - & * & - & - & - & 0.21 & 0.23 \\
\hline $\begin{array}{l}\text { Poecilia } \\
\text { velifera }\end{array}$ & $4.5-10$ & $4.3-7.5$ & 29 & 17 & 98.09 & 100 & $*$ & - & - & - & $*$ & - & - & - & - & - & - & - & $*$ & - & 0.01 & $\mathbf{0}$ \\
\hline $\begin{array}{l}\text { Poecilia } \\
\quad \text { mexicana }\end{array}$ & $6.7-13$ & $7-8.1$ & 15 & 12 & 48.84 & 100 & 51.15 & - & - & - & - & - & - & - & - & - & - & - & - & - & 0.03 & $\mathbf{0}$ \\
\hline $\begin{array}{l}\text { Belones } \\
\quad \text { oxbelizanus }\end{array}$ & $11-13$ & - & 22 & - & - & - & - & - & - & - & - & - & - & - & - & - & - & - & 100 & - & $\mathbf{0}$ & - \\
\hline $\begin{array}{l}\text { Rocio } \\
\quad \text { octofasciata }\end{array}$ & $4-6.5$ & $3.5-6.9$ & 11 & 13 & 76.47 & 57.14 & - & - & - & - & 18.38 & - & - & 14.2 & $*$ & - & * & 28.57 & - & - & 0.20 & 0.66 \\
\hline $\begin{array}{l}\text { Cichlasoma } \\
\text { salvini }\end{array}$ & $6.2-8$ & - & 31 & - & 78.1 & - & - & - & - & - & 19.52 & - & * & - & $*$ & - & - & - & - & - & 0.18 & - \\
\hline $\begin{array}{l}\text { Petenia } \\
\quad \text { splendida }\end{array}$ & $\begin{array}{l}17.9- \\
24.3\end{array}$ & - & 10 & - & - & - & - & - & - & - & - & - & - & - & - & - & - & - & 100 & - & 0 & - \\
\hline $\begin{array}{l}\text { Oreochromis } \\
\text { niloticus }\end{array}$ & $10.5-24$ & - & 16 & - & 99.8 & - & * & - & - & - & - & - & - & - & - & - & - & - & - & - & 0.01 & - \\
\hline $\begin{array}{l}\text { Paraneetroplus } \\
\text { melanurus }\end{array}$ & $8.6-17.7$ & - & 25 & - & 12.51 & - & 71.30 & - & * & - & $*$ & - & $*$ & - & $*$ & - & * & - & $*$ & - & 0.12 & - \\
\hline $\begin{array}{l}\text { Garmanella } \\
\text { pulchra }\end{array}$ & - & $2.5-4.3$ & - & 10 & - & 97.67 & - & - & - & - & - & * & - & - & - & - & - & - & - & - & - & 0.05 \\
\hline
\end{tabular}

included in the diet of G. yucatana and A. aeneus (Fig. 2). Conversely, fish in SP pools showed affinity for terrestrial invertebrates. Here, fish showed significantly higher frequencies of Heteroptera (A. aeneus) and Arachnida $(R$. octofasciata) $(t=1.77,1.45, p<0.05, n=13$, respectively) compared to P pools (Fig. 2). These species were present in both habitats, showing contrasting diets. When items were grouped in broader categories and compared by SIMPER between seasons, individuals from $\mathrm{P}$ pools showed low variation between seasons ( $22.78 \%$ dissimilarity). During the dry season detritus $(6.16 \%)$, fish remains $(5.23 \%)$, gastropod $(4.19 \%)$, plant remains $(2.85 \%)$ and algae $(2.66 \%)$ account for this variation. Conversely, items consumed in SP showed a strong seasonality effect during the rainy season with $41.1 \%$ dissimilarity. Detritus (13\%), aquatic insects $(9 \%)$, terrestrial invertebrates (7.1\%), fish remains (7\%) and arachnids (5\%) account for this variation. In P pools detritus was consumed in higher proportions in both seasons. During the dry season fish eat more on fish and plant remains, aquatic insects and algae while during the rainy season fed more on plant remains, algae and gastropod (Fig. 3). Fish in SP pools fed more on detritus and fish remains during the dry season switching to aquatic and terrestrial insects and arachnids during the rainy season (Fig. 3).

Diet overlaps between species were present in both habitats but with highly different frequencies. In P pools, $50 \%$ of niche overlaps were intermediate, $37 \%$ were high (biologically significant) and $15 \%$ were low (Table 4). Despite scarce fish interactions in SP pools, the greatest recorded overlaps were

Table 3. Trophic Habits (TH; based on Levins, 1968) and Trophic Classification (TC) (modified from Schlosser, 1982 and Karr et al., 1986) for fish in permanent (P) and semipermanent (SP) pools of the PBR during 2010. $G=$ generalist and $\mathrm{S}=$ specialist habits. $\mathrm{D}=$ detritivorous, $\mathrm{O}=$ omnivorous, $\mathrm{M}=$ malacophagous, $\mathrm{HD}=$ herbivorous-detritivorous, $\mathrm{P}=$ piscivorous and I = insectivorous. INB (Index of niche breadth) for each species between pools.

\begin{tabular}{lcccccc}
\hline \multicolumn{1}{c}{ Species } & TH & TC & \multicolumn{5}{c}{ TH } & TC & \\
& $\mathrm{P}$ & $\mathrm{P}$ & $\mathrm{INB}$ & $\mathrm{SP}$ & $\mathrm{SP}$ & $\mathrm{INB}$ \\
\hline Cichlasoma urophthalmus & $\mathrm{S}$ & $\mathrm{D} / \mathrm{O}$ & 0.3 & - & - & - \\
Thorichthys meeki & $\mathrm{S}$ & $\mathrm{M} / \mathrm{D}$ & 0.2 & - & - & - \\
Astyanax aeneus & $\mathrm{S}$ & $\mathrm{I} / \mathrm{HD}$ & 0.31 & $\mathrm{G}$ & $\mathrm{I} / \mathrm{O}$ & 0.55 \\
Rocio octofasciata & $\mathrm{S}$ & $\mathrm{D}$ & 0.2 & $\mathrm{G}$ & $\mathrm{O}$ & 0.66 \\
Gambusia yucatana & $\mathrm{S}$ & $\mathrm{O}$ & 0.21 & $\mathrm{~S}$ & $\mathrm{I}$ & 0.23 \\
Poecilia mexicana & $\mathrm{S}$ & $\mathrm{HD}$ & 0.03 & $\mathrm{~S}$ & $\mathrm{D}$ & 0 \\
Poecilia velifera & $\mathrm{S}$ & $\mathrm{D}$ & 0.01 & $\mathrm{~S}$ & $\mathrm{D}$ & 0 \\
Belonesox belizanus & $\mathrm{S}$ & $\mathrm{P}$ & 0 & - & - & - \\
Cichlasoma salvini & $\mathrm{S}$ & $\mathrm{D}$ & 0.18 & - & - & - \\
Oreochromis niloticus & $\mathrm{S}$ & $\mathrm{D}$ & 0.0 & - & - & - \\
Petenia splendida & $\mathrm{S}$ & $\mathrm{P}$ & 0 & - & - & - \\
Paraneetroplus melanurus & $\mathrm{S}$ & $\mathrm{HD}$ & 0.12 & - & - & - \\
Garmanella pulchra & - & - & - & $\mathrm{S}$ & $\mathrm{D}$ & 0.05 \\
\hline
\end{tabular}




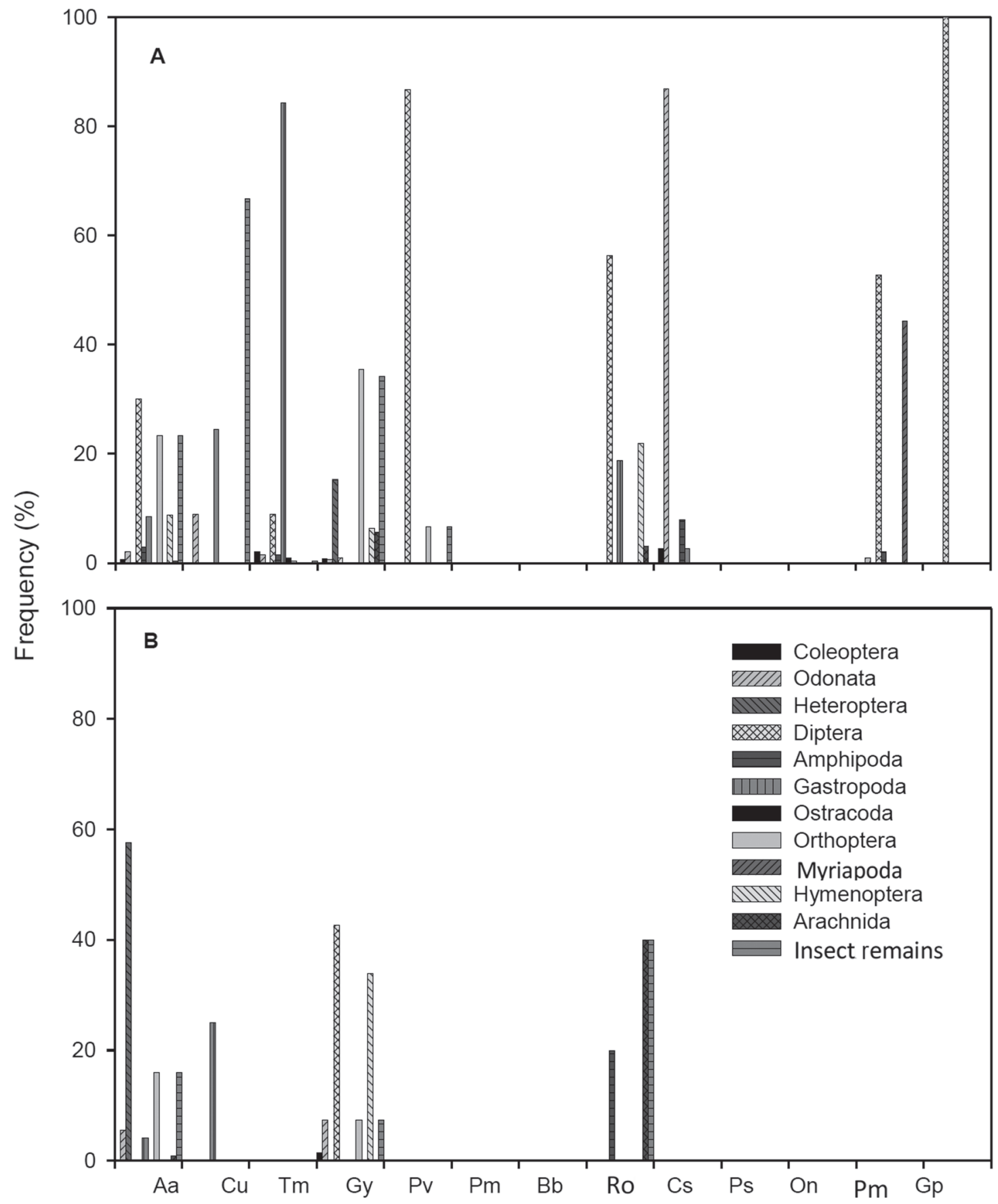

Fig. 2. Fish feeding spectrum of aquatic insects and terrestrial invertebrates (proportions of different orders in the diet of all stomachs analyzed) between Permanent (A) and Semi-permanent (B) pools in the PBR during 2010. Species codes: Aa = Astyanax aeneus, $\mathrm{Cu}=$ Cichlasoma urophthalmus, $\mathrm{Tm}=$ Thorichthys meeki, $\mathrm{Gy}=$ Gambusia yucatana, $\mathrm{Pv}=$ Poecilia velifera, $\mathrm{Pm}=$ P. mexicana, $\mathrm{Bb}=$ Belonesox belizanus, $\mathrm{Ro}=$ Rocio octofasciata, $\mathrm{Cs}=$ Cichlasoma urophthalmus, $\mathrm{Ps}=$ Petenia splendida, $\mathrm{On}=$ Oreochromis niloticus, $\mathrm{Pm}=$ Paraneetroplus melanurus, $\mathrm{Gp}=$ Garmanella pulchra .

intermediate-low. Poecilia velifera had the most pronounced diet overlap of all the species analyzed, particularly with Oreochromis niloticus, C. salvini, R. octofasciata, G. yucatana and $P$. mexicana in P pools, whereas it had only one significant interaction in SP pools with G. pulchra. The C. urophthalmus diet also showed high overlap values with $O$. niloticus and $C$. salvini diets $(>0.9)$ and to a lesser extent with the $P$. velifera (0.69) diet. In P pools, A. aeneus showed a biologically significant overlap with $C$. urophthalmus, which reflects the proportion of detritus and plant remains in their diets. Paraneetroplus melanurus and P. mexicana had a high diet overlap based on the use of plant remains in P pools. Rocio 

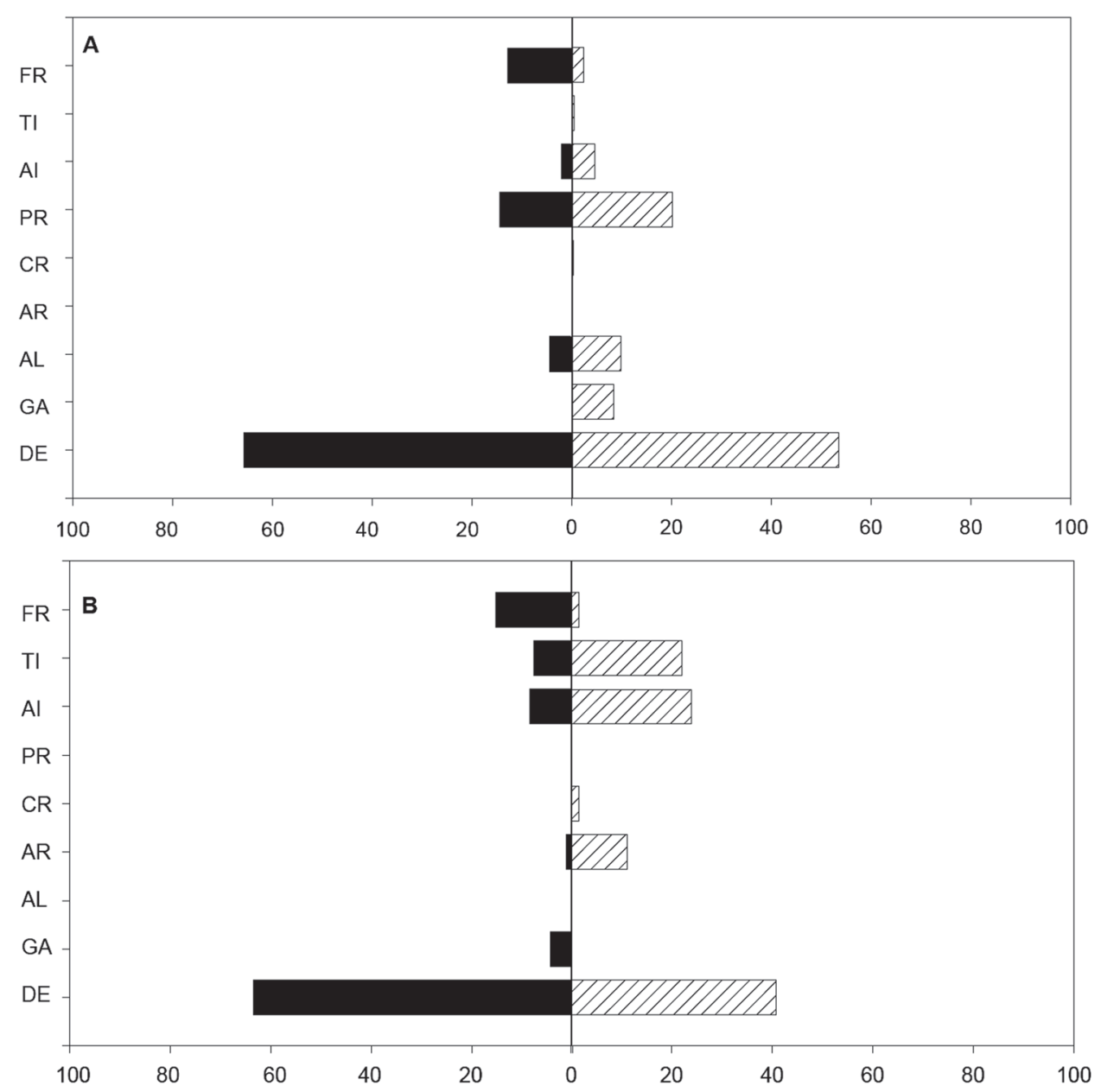

Fig. 3. Percentage composition of main items consumed by fish in Permanent (A) and Semi-permanent (B) pools in BPR during the dry (black bars) and rainy season (dash bars) of 2010. $\mathrm{FR}=$ fish remains, $\mathrm{TI}=$ terrestrial invertebrates, $\mathrm{AI}=$ aquatic insects, $\mathrm{PR}=$ plant remains, $\mathrm{CR}=$ crustaceans (mainly amphipods), $\mathrm{AR}=$ arachnid, $\mathrm{AL}=$ algae, $\mathrm{GA}=$ gastropod and $\mathrm{DE}=$ detritus .

octofasciata exhibited high diet similarity with detritivorous species such as P. velifera and T. meeki (Table 4).

\section{Discussion}

The analysis of fish stomachs showed that fish in pools of the PBR use a wide variety of food sources, especially detritus, aquatic insects and terrestrial invertebrates, plants, gastropod, and fish remains. Most species associated to permanent waters showed a specialized diet with a generalist tendency in ephemeral pools, in which fish take advantage of changing prey abundance. An interesting condition was observed in fish species present in both types of water bodies which exhibited opposite diet and trophic classification. This suggests that fish in pools of the PBR can modify their diet based on variations of food sources and prey abundance. This diet modification appears to be driven by pool hydrology, particularly in SP pools (see Winemiller \& Jepsen, 1998). For instance, in a previous study at the same pools, aquatic invertebrate abundance was analyzed. P pools showed an average abundance of 66 ind. $/ \mathrm{m}^{2}$ while in SP pools 48 ind. $/ \mathrm{m}^{2}$ as well as different community composition (Hinojosa-Garro et al., 2009). As result, variations in prey abundance between pools were also observed in fish diet composition. Species present in SP pools almost always had empty stomachs and lower relative fullness values, suggesting a lower food base, compared to $\mathrm{P}$ pools, in which fish stomachs were almost twice as full and had a constant feeding pattern. Despite variations in pool hydrology and seasonality, detritus was the main item in all fish diets, followed by aquatic insect and terrestrial invertebrates. Detritus, which includes particulate organic matter, mud and epiphytic algae, is extremely abundant in most areas of the reserve, particularly in P waters (Vega-Cendejas \& Arreguín-Sánchez, 2001). As a result, detritivorous fish species were well represented in both habitats, with the highest diet overlap. This important source of energy can enhance community efficiency, being a prime source in the 
Table 4. Diet overlap (according to Pianka, 1974) of all fish analyzed in pools of the PBR during 2010. Values in bold represent biologically significant niche overlapping (according to Langton, 1982) in permanent pools while parenthesis represents those overlapping values in semi-permanent pools. Overlap range: $\operatorname{High}(>0.6)$, intermediate $(0.4-0.6)$ or low $(<0.4)$ (Grossman, 1986).

\begin{tabular}{ccccccccc}
\hline Species & C. urophthalmus & A. aeneus & T. meeki & P. velifera & P. mexicana & G. yucatana & C. salvini & O. niloticus \\
\hline Paraneetroplus melanurus & 0.17 & 0.17 & 0.08 & 0.18 & $\mathbf{0 . 9 4}$ & 0.2 & 0.19 & 0.17 \\
Oreochromis niloticus & $\mathbf{0 . 9 9}$ & 0.53 & 0.29 & $\mathbf{0 . 9 9}$ & 0.46 & 0.48 & $\mathbf{0 . 9 6}$ & - \\
Cichlasoma salvini & $\mathbf{0 . 9 7}$ & 0.52 & 0.31 & $\mathbf{0 . 9 9}$ & 0.44 & $\mathbf{0 . 6 7}$ & - & - \\
Belonesox belizanus & 0.41 & $(0.02)$ & 0.32 & - & - & - & - & \\
Rocio octofasciata & 0.09 & 0.34 & $\mathbf{0 . 9 2}$ & $\mathbf{0 . 9 7}$ & - & 0.1 & \\
Garmanella pulchra & - & - & - & $\mathbf{( 0 . 9 9 )}$ & - & & \\
Gambusia yucatana & 0.51 & $\mathbf{( 0 . 8 7 )}$ & 0.22 & $\mathbf{0 . 7 5}$ & 0.47 & & \\
Poecilia mexicana & 0.45 & $\mathbf{( 0 . 6 9 )}$ & 0.16 & $\mathbf{0 . 7 2}$ & & & \\
Poecilia velifera & $\mathbf{0 . 6 9}$ & 0.44 & $\mathbf{0 . 7 4}$ & - & & & \\
Thorichthys meeki & 0.52 & 0.43 & - & & & & \\
Cichlasoma urophthalmus & - & $\mathbf{0 . 8 8}$ & & & & & \\
Petenia splendida & $\mathbf{0 . 9 0}$ & & & & & &
\end{tabular}

food chain and can also enhance epibenthic resources which will also be included in the fish diet (Catella \& Petrere, 1996; Vaz et al., 1999). Aquatic insects and terrestrial invertebrates were the second most frequent items in fish diets. In SP pools, terrestrial insects and invertebrates were present in fish diets, whereas fish in P pools showed more affinity for aquatic invertebrates. The presence of Odonata, Diptera, and Heteroptera might relate to their high abundance in these water bodies (Hinojosa-Garro et al., 2009). INB values suggest that fish that inhabit SP pools use the most food sources available (e.g., terrestrial invertebrate and crustaceans), which results in higher values, and they might respond to fluctuations in food abundance and type (Crowder \& Cooper, 1982), as do Cichlids and Characids. Conversely, in P pools, Cichlids in general showed lower INB values, probably as a result of a more specialized feeding strategy, which is an outcome of a wider variety of food sources being available, particularly for items such as fish and plant remains, gastropod and aquatic insects (Hinojosa-Garro et al., 2009). Previous studies in Central America showed that neotropical Cichlids experience a diet shift based on water hydrology, ranging from algae and detritus, to insects, crustaceans, and fish (Eaton, 1943; Winemiller et al., 1995; Valtierra-Vega \& Schmitter-Soto, 2000; Waltzek \& Wainwright, 2003). In our study fish described opposite trophic habits based on pools hydrology, with a tendency of specialist feeders in P pools while generalist feeders in SP pools. Although this condition is unusual in seasonal habitats, it has been observed in some studies carried out in tropical ponds and streams a diet specialization - steady low INB values between seasons - and low omnivorous species, despite the use of a wide range of food items, as result of steady food sources and low variation between seasons (Novakowski, et al., 2008; Mazzoni et al., 2010; Schneider et al., 2011). The absence of seasonal variation and the predominance of autochthonous items in the fish diet are probably associated to permanent waters which will enhanced aquatic flora and fauna. A similar condition was observed in P pools in which fish exhibit low INB values and variation in items proportion between seasons, with an opposite condition in SP pools. In dry periods fish inhabiting P pools use more detritus and plants/fish remains while in SP pools detritus and fish remains. In the rainy season $\mathrm{P}$ pools fish showed a different feeding pattern using plants remains, gastropod and algae while aquatic insects and terrestrial invertebrate in SP pools; probably as result of allochthonous inputs. Thus, seasonality enhances prey variations in pools, particularly in those ephemeral, which influence the number of food sources and their proportion in fish diet of PBR (see Winemiller, 1990; Silva et al., 2012). Nonetheless, the Cichlid diet composition in the peninsula might be much more dynamic than has been described in other tropical regions (Winemiller et al., 1995; Waltzek \& Wainwright, 2003). For example, T. meeki in lagoons of Quintana Roo was described as planktivorous (Navarro-Mendoza, 1988; Valtierra-Vega \& Schmitter-Soto, 2000), in contrast to our findings, suggesting that fish species from this family cope with variations in habitat type by modifying their feeding strategies on a regional scale. For instance, the only Cichlid (R. octofasciata) that was present in both types of habitats fed selectively on Diptera in P pools, and switched to Arachnida in SP pools. In the same study, C. salvini was described as feeding on Copepods, Chironomids and Ostracods (Valtierra-Vega \& Schmitter-Soto, 2000), whereas we observed a diet mainly comprised of detritus and aquatic insects. Thus, Cichlids are very adaptable and appear to alter main items in their diet on a regional scale, mainly based on available food sources. Alternatively, Poeciliidae showed contrary feeding strategies between pools. Fish in $P$ pools exhibited a generalist pattern, using a wide range of food sources (e.g., G. yucatana and P. mexicana) from algae to fish remains, whereas in SP pools they became specialists, feeding mainly on aquatic insects and detritus. Fish in this family are well adapted to water conditions in the peninsula (Miller, 2009). Gibb et al. (2008) observed that poeciliids have developed jaw adaptations that are likely to enhance performance when feeding on attached or encrusted food items. This might explain the differences 
in feeding behavior and habits compared to the other taxonomic group found. Cyprinodontid showed a high affinity for detritus, as has been reported for other similar shallow water bodies of the Yucatan peninsula (Miller, 2009). Feeding overlaps between species were common in $P$ pools and most were biologically significant (according to Langton, 1982), with intermediate and high interactions. These extensive overlaps were probably associated with the high abundance of common prey used by fish, particularly in P pools. It has been observed in similar systems, that a food type that is widely and continually available can favor non-restrictive trophic specialization (Silva et al., 2012), which agrees with INB results, in which species showed lower values as a feeding strategy, particularly in P pools. Furthermore, high values of diet overlap ( $>0.6$ ) were observed among detritivorous species (homogeneous diets). Intermediate values were obtained mainly for pairs of species that consumed more than one type of food resource (with a dominance of one or two types). In contrast, fish in SP pools described intermediatelow overlap values $(<0.4)$, based on the use of more food sources available in this habitat, which in turn resulted in higher INB values.

The results, therefore, show that for these coastal freshwater wetland species, coexistence and trophic conditions appear to depend on pools hydrology, as result of food sources (e.g., prey richness and abundance) promoting variations in fish feeding habits on a regional scale (diet specialization), compared with other $\mathrm{P}$ water bodies in the Yucatan peninsula. Our results contribute to a better understanding of whether fish diets are based on pool hydrology in tropical wetlands, which constitutes the baseline for further studies involving freshwater fish species conservation in the PBR, but also in the Yucatan Peninsula. Results also emphasize the importance of shallow pools for fish species distribution in wetlands of the Yucatan peninsula, an area with lack of information about freshwater fish biology.

\section{Acknowledgments}

We are grateful to Adriana M. Burgos Chan, Manuel Magaña Cohuo, José Tucuch May, and Ricardo Góngora Chin for their help during the fieldwork. We thank the Petenes Reserve warden, César Romero Herrera, for allowing us to work in the PBR. This study was funded by the Programa del Mejoramiento de Profesorado (PROMEP 103.5/10/0674), Mexico.

\section{Literature Cited}

Catella, A. C. \& M. Petrere Jr. 1996. Feeding patterns in a fish community of Bahía da Onca, a floodplain lake of the Aquidauana river, Pantanal, Brazillian Fish Management Ecology, 3: 229237.
Clarke, K. R. \& R. N. Gorley. 2006. PRIMER v6: User Manual/ Tutorial. PRIMER-E, Plymouth.

Cochran-Biederman, J. L. \& K. O. Winemiller. 2010. Relationships among habitat, ecomorphology and diets of cichlids in the Bladen River, Belize. Environmental Biology of Fish, 88: 143-152.

CONANP. 2006. Programa de Conservacion y Manejo de la Reserva de la Biosfera Los Petenes.

Contreras-Espinosa, F. \& B. G. Warner. 2004. Ecosystem characteristics and management considerations for coastal wetlands in Mexico. Hydrobiologia, 511: 233-245.

Crowder, L. B. \& W. E. Cooper. 1982. Habitat structural complexity and the interaction between bluegills and their prey. Ecology, 63: 1802-1813.

Dias, T. S. \& C. B. Fialho. 2009. Biologia alimentar de quatro espécies simpátricas de Cheirodontinae (Characiformes, Characidae) do rio Ceará Mirim, Rio Grande do Norte. Iheringia, Série Zoologia, 99: 242-248.

Dias, T. S. \& C. B. Fialho. 2011. Comparative dietary analysis of Eurycheilichthys pantherinus and Pareiorhaphis hystrix: two Loricariidae species (Ostariophysi, Siluriformes) from Campos Sulinos biome, southern Brazil. Iheringia, Série Zoologia, 101: 49-55.

Eaton, T. H. 1943. An adaptive series of protractile jaws in cichlid fishes. Journal of Morphology, 72: 183-190.

Escalera-Vázquez, L. H. \& L. Zambrano. 2010. The effect of seasonal variation in abiotic factors on fish community structure in temporary and permanent pools in a tropical wetland. Freshwater Biology, 55: 2557-2569.

García, E. 1973. Modificaciones al sistema de Clasificación Climática de Köppen para adaptarlo a las condiciones de la República Meixcana). Instituto de Geofísica, Universidad Nacional Autónoma de México.

Gibb, A., L.A. Ferry-Graham, L.P. Hernandez, R. Romansco \& J. Blanton. 2008. Functional significance of intramandibular bending in Poeciliid fishes. Environmental Biology of Fish, 83: 507-519.

Grossman, G. D. 1986. Food resources partitioning in a rocky intertidal fish assemblage. Journal of Zoology, 1: 317-355.

Hahn, N. S., R. Fugi \& I. F. Andrian. 2004. Trophic ecology of the fish assemblages. Pp. 247-269. In: Thomaz, S. M., A. A. Agostinho \& N. S. Hahn. (Eds.). The Upper Paraná River and its Floodplain: physical aspects, ecology and conservation. Leiden, Backhuys.

Hinojosa-Garro, D., J. Angulo, A. Domínguez, A. Burgos, A. Magaña \& J. Arceo. 2009. Estructura de comunidades acuáticas y calidad de agua en sistemas humedales dulceacuícolas de la Reserva de la Biósfera los Petenes, Campeche: estrategias de biomonitoreo como herramientas para la conservación de ecosistemas acuáticos tropicales. Universidad Autónoma de Campeche, Informe final PROMEP.

Hyslop, E. J. 1980. Stomach contents analysis. A review of methods and their application. Journal of Fish Biology, 17: 411-429.

Karr, J. R., K. D. Fausch, P. L. Angermeier, P. R. Yant \& I. J. Schlosser .1986. Assessment of Biological Integrity in Running Waters: a Method and its Rationale. Illinois Natural Survey Illinois Special Publication, 5: 28.

Krebs, C. J. 1989. Ecological methodology. Harper and Row, New York.

Langton, R. W. 1982. Diet overlap between the Atlantic cod Gadus morhua, silver hake Merluccius bilinearis and fifteen other northwest Atlantic finfish. Fishery Bulletin, 80: 745-759. 
Levins, R. 1968. Evolution in Changing Environment: Some Theoretical Explorations. Princeton University Press, Princeton, New Jersey.

Lima-Junior, S. E. \& R. Goitein. 2001. A new method for the analysis of fish stomach contents. Acta Scientiarum, 23: 421-424.

Martínez-Palacios, C. A. \& L. G. Ross. 1994. Biología y cultivo de la mojarra latinoamericana: Cichlasoma urophthalmus. Consejo Nacional de Ciencia y Tecnología/Centro de Investigación para la Alimentación y el Desarrollo, México.

Mazzoni, R., R. R. da S. Araújo, G. C. T. dos Santos \& R. IglesiasRios. 2010. Feeding ecology of Phalloceros anisophallos (Osteichthyes: Cyprinodontiformes) from Andorinha Stream, Ilha Grande, Brazil. Neotropical Ichthyology, 8: 179-182.

Mérona, B. \& J. R. Mérona. 2004. Food resource partitioning in a fish community of central Amazon floodplain. Neotropical Ichthyology, 2: 75-84.

Miller, R. R. 2009. Peces dulceacuícolas de México. Comisión Nacional para el Conocimiento y Uso de la Biodiversidad (CONABIO), México D.F..

Navarro-Mendoza, M. 1988. Inventario íctico y estudios ecológicos preliminares de los cuerpos de agua continentales en la reserva de la biosfera de Sian Ka'an y áreas circunvecinas en Quintana Roo, México. Centro de Investigaciones de Quintana Roo/ Secretaría de Desarrollo Urbano y Ecología/ United States Fish $\&$ Wildlife Service, Chetumal, México.

Novakowski, G. C., N. S. Hahn \& R. Fugi. 2008. Diet seasonality and food overlap of the fish assemblage in a pantanal pond. Neotropical Ichthyology, 6: 567-576.

Pianka, E. R. 1974. The structure of lizard communities. Annual Review of Ecology and Systematics, 4: 53-74.

Pouilly, M., S. Barrera \& C. Rosales. 2006. Changes of taxonomic and trophic structure of fish assemblages along an environmental gradient in the Upper Beni (Bolivia). Journal of Fish Biology, 68: 137-156.

Reinthal, P. N. 1990. The feeding habits of a group of herbivorous rock-dwelling cichlid fishes (Cichlidae: Perciformes) from Lake Malawi, Africa. Environmental Biology of Fishes, 27: 215-233.

Schmitter-Soto, J. J. 1998. Catálogo de los peces continentales de Quintana Roo. ECOSUR.

Schlosser, I. J. 1982. Fish community structure and function along two habitat gradients in head water stream. Ecological Monographs, 52: 395-474.

Schneider, M., P. D. P. U. de Aquino, M. J. M. Silva \& C. P. Fonseca. Trophic structure of a fish community in Bananal stream subbasin in Brasília National Park, Cerrado biome (Brazilian Savanna), DF, Neotropical Ichthyology, 9: 579-592.
Silva, C. J., R. L. Delariva K. \& O. Bonato. 2012. Food-resource partitioning among fish species from a first-order stream in northwestern Paraná, Brazil. Neotropical Ichthyology, 6: $567-$ 576.

Taylor, C. M. 1997. Fish species richness and incidence patterns in isolated and connected stream pools: effects of pool volume and spatial position. Oecologia, 110: 560-566.

Torres-Castro, I. L., M. E. Vega-Cendejas, J. J. Schmitter-Soto, G. Palacio-Aponte \& R. Rodiles-Hernández. 2008. Ictiofauna de sistemas cárstico-palustres con impacto antrópico: los petenes de Campeche, México. Revista de Biología Tropical, 57: 141157.

Valtierra-Vega, M. T. \& J. J. Schmitter-Soto. 2000. Hábitos alimentarios de las mojarras (Perciformes: Cichlidae) de la laguna Caobas, Quintana Roo, México. Revista Biología Tropical, 48: $1-11$.

Vega-Cendejas, M. E. \& F. Arreguín-Sánchez. 2001. Energy fluxes in a mangrove ecosystem from a coastal lagoon in Yucatan Peninsula, Mexico. Ecological Modelling, 137: 119-133.

Vaz, M. M., M. Jr. Petrere, L. A. Martinelli \& A. A. Mozeto. 1999. The dietary regime of detritivorous fish from the river Jacaré Pepira, Brazil. Fisheries Management and Ecology, 6: 121-132.

Waltzek, T. B. \& P. C. Wainwright. 2003. Functional morphology of extreme jaw protrusion in Neotropical cichlids. Journal of Morphology, 257: 96-106.

Winemiller, K. O. 1990. Spatial and temporal variation in tropical fish trophic networks. Ecological Monographs, 60: 331-367.

Winemiller, K. O. \& D. B. Jepsen. 1998. Effects of seasonality and fish movement on tropical river food webs. Journal of Fish Biology, 53: 267-296.

Winemiller, K. O., L. C. Kelso-Winemiller \& A. L. Brenkert. 1995. Ecological and morphological diversification in fluvial cichlid fishes. Environmental Biology of Fish, 44: 235-261.

Yamamoto, K. C. 2004. Alimentação de Triportheus angulatus (Spix \& Agassiz, 1829) no lago Camaleão, Manaus, AM, Brasil. Acta Amazônica, 34: 653-659.

Zambrano, L., E. Vázquez-Domínguez, D. García-Bedoya, Loftus W. F. \& Trexler J. C. 2006. Fish community structure in freshwater karstic waterbodies of the Sian $\mathrm{Ka}$ 'an Reserve in Yucatan peninsula, Mexico. Ichthyological Exploration of Freshwater, 17: 193-20.

Submitted December 13, 2012 Accepted August 19, 2013 by Norma S. Hahn Published December 27, 2013 